\title{
PENGELOMPOKKAN KECAMATAN DI TULUNGAGUNG BERDASARKAN PRODUKSI TELUR MENURUT JENIS UNGGAS DENGAN MENGGUNAKAN ANALISIS KLASTER
}

\author{
Nika Marathus Sholihah ${ }^{1)}$ \\ Artanti Indrasetianingsih ${ }^{2)}$ \\ ${ }^{1)}$ S1 Program Studi Statistika, FMIPA, Universitas PGRI Adi Buana Surabaya \\ ${ }^{2)}$ Program Studi Statistika, FMIPA, Universitas PGRI Adi Buana Surabaya
}

\begin{abstract}
ABSTRAK
Analisis klaster adalah suatu metode multivariate yang bertujan untuk mengelompokkan obyek berdasarkan kemiripan atau ketidakmiripan karakteristiknya, sehingga objek yang terletak pada satu klaster memiliki kemiripan yang lebih besar dibandingkan dengan objek pengamatan yang terletak pada klaster lain. K-Means merupakan salah satu metode pengklasteran tidak hirarki. Pada penelitian ini digunakan data produksi telur menurut jenis unggas pada 17 kecamatan di kabupaten Tulungagung Tahun 2011. Tujuan dari penelitian ini adalah untuk mendapatkan pengelompokkan kecamatan di Tulungagung berdasarkan produksi telur menurut jenis unggas dengan menggunakan analais K-Means klaster. Analisis klaster K-Means setelah ditentukan kelompoknya sebanyak 3 diperoleh hasil kelompok kecamatan yang rendah produksi telurnya (ada 11 kecamatan : Basuki, Bandung, Pakel, Campurdarat, Pucanglaban, Boyolangu, Tulungagung, Karangrejo, Kauman, Gondang, dan Sendang), kelompok kecamatan dengan produksi telur sedang (ada 5 kecamatan : Kalidawir, Ngunut, Sumbergempol, Kedungwaru dan Ngantru), sedangkan kelompok kecamatan dengan produksi telur tinggi adalah kecamatan Rejotangan.
\end{abstract}

Kata kunci : $K$-mean, produksi telur, unggas,

\section{Pendahuluan}

Pembangunan sektor peternakan merupakan bagian dari pertumbuhan industri pertanian, dimana sektor tersebut memiliki nilai strategis dalam memenuhi kebutuhan pangan yang terus meningkat seiring dengan bertambahnya jumlah penduduk Indonesia. Pembangunan sektor peternakan tersebut turut mendukung program pemerintah dalam rangka peningkatan gizi masyarakat dan juga sebagai salah satu pendukung ketahanan pangan Nasional (Saragih, 2000).

Industri ayam petelur sebagai salah satu penunjang industry pertanian mampu memberikan kontribusi terhadap PDB nasional sebesar 3,8\% pada tahun 2002. Data yang diterbitkan oleh BPS (Badan Pusat Statistik, 2004) menunjukan bahwa pada tahun 2003 terjadi peningkatan populasi Ayam ras petelur sebesar $8,27 \%$ dibanding dengan tahun 2002. Peningkatan jumlah ayam ras petelur 
tersebut berdampak pada peningkatan jumlah produksi telur sebesar 6,89\% pada tahun yang sama (Deptan, 2004).

Data yang bersumber dari Badan Pusat Statistik (BPS) Tulungagung (2012). Produksi telur menurut jenis Unggas untuk seluruh Kecamatan di kabupaten Tulungagung menunjukkan peningkatan produksi telur dari tahun 2007 sampai 2011 untuk jenis unggas ayam kampung, mentok dan puyuh.

Data yang digunakan pada penelitian ini adalah data produksi telur menurut jenis unggas pada 17 kecamatan di kabupaten Tulungagung Tahun 2011. Tujuan dari penelitian ini adalah untuk mendapatkan pengelompokkan kecamatan di Tulungagung berdasarkan produksi telur menurut jenis unggas dengan menggunakan analais $K$-Means klaster.

\section{K-Means Klaster}

Analisis kelompok atau yang biasa dikenal sebagai cluster analysis adalah salah satu teknik statistik yang bertujuan untuk mengelompokkan objek kedalam suatu kelompok sedemikian sehingga objek yang berada dalam satu kelompok akan memiliki kesamaan yang tinggi dibandingkan dengan objek yang berada di kelompok lain (Sharma, 1996:185). Secara umum dalam metode analisis kelompok, terdapat dua metode pengelompokkan, yaitu metode hierarki (Hierarchical Methods) dan metode tak berhierarki (Nonhierarchical Methods) (Johnson \& Wichern, 2002).

Metode K-Means merupakan metode pengelompokan yang bertujuan mengelompokkan objek sedemikian sehingga jarak tiap-tiap objek ke pusat kelompok di dalam satu kelompok adalah minimum. K-means klater merupakan salah satu metode pengelompokan data non-hirarki yang membagi data menjadi dua atau lebih kelompok, yakni memproses semua objek secara sekaligus. Proses ini dimulai dengan penentuan jumlah klaster terlebih dahulu.

\section{Metodologi Penelitian}

Data yang digunakan dalam penelitian ini adalah data sekunder.Data tersebut diperoleh dari BPS Tulungagung Tahun 2012.Data yang digunakan merupakan data produksi telur menurut jenis unggas.Pada 17 kecamatan di 
kabupaten Tulungagung Tahun 2011. Variabel-variabel yang digunakan dalam penelitian ini sebagai berikut :

1) Jumlah produksi telur ayam kampung $\left(\mathrm{X}_{1}\right)$, yaitu produksi telur yang dihasilkan oleh ayam kampung dengan satuan kilogram $(\mathrm{kg})$ disetiap kecamatan di kabupaten Tulungagung.

2) Jumlah produksi telur ayam ras $\left(X_{2}\right)$, produksi telur yang dihasilkan oleh ayam ras dengan satuan kilogram $(\mathrm{kg})$ disetiap kecamatan dikabupaten Tulungagung.

3) Jumlah produksi telur telur itik $\left(\mathrm{X}_{3}\right)$, produksi telur yang dihasilkan oleh itik dengan satuan kilogram (kg) disetiap kecamatan dikabupaten Tulungagung.

4) Jumlah produksi telur telur mentok $\left(\mathrm{X}_{4}\right)$, produksi telur yang dihasilkan oleh mentok dengan satuan kilogram $(\mathrm{kg})$ disetiap kecamatan dikabupaten Tulungagung.

5) Jumlah produksi telur telur puyuh $\left(\mathrm{X}_{5}\right)$, Produksi Telur yang dihasilkan oleh puyuh dengan satuan kilogram $(\mathrm{kg})$ disetiap kecamatan dikabupaten Tulungagung.

Tahapan analisis data yang dilakukan ada 2 tahap, yaitu analisis deskriptif dan analisis k-means Klaster.

1) Analisis Deskriptif

Analisis deskriptif disajikan dalam bentuk tabel serta grafik mengenai tingkat produksi telur di Kabupaten Tulungagung.

2) Pengujian Asumsi Analisis Klaster

a. Kecukupan data . Kecukupan data diuji dengan menggunakan KMO (Kaiser Meyer Olkin).

b. Uji Multikolinieritas. Ada tidaknya kasus multikolinier dapat dilihat dari nilai VIF (Variance Inflation Faktor). Ada kasus multiko jika nilai VIF lebih dari 10.

3) Analisis $K$-Means

Setelah data diperoleh langkah selanjutnya adalah melakukan analisis data dengan menggunakan metode K-means klaster. Tahapan analisis yang dilakukan sebagai berikut: 
1. Menentukan banyaknya klaster yang akan dibentuk.

Dalam penelitian ini klaster yang ingin dibentuk adalah 3 klaster.

2. Lakukan metode pengklasteran K-Means dengan k klaster yang didapat pada langkah 1 . Tahapan yang dilakukan pada metode kmeans adalah sebagai berikut :

a. Menentukan pusat klaster awal secara acak.

b. Menghitung jarak antara setiap objek dengan pusat klaster

c. Masukkan tiap objek ke satu klaster yang memiliki jarak terdekat dengan pusat klaster.

d. Menghitung kembali pusat klaster yang terbentuk

e. Ulangi dari langkah b sampai tidak ada perpindahan objek antar klaster.

3. Mendeskripsikan karakteristik klaster

Dalam mendeskripsikan klaster digunakan persamaan sebagai berikut:

$x=\frac{\sum x_{i j}}{n_{j}} i=1,2,3 \ldots \ldots n \quad j=1,2,3 \ldots \ldots q$

Dengan $X=$ Rata-rata sampel (rata-rata variabel pada klaster tertentu).

$x_{i j}=$ nilai data ke-i pada variabel ke-j

$n_{j}=$ banyaknya anggota pada klaster ke-j

\section{Hasil dan Pembahasan}

Hasil analisis deskriptif untuk melihat gambaran dari data produksi telur berdasarkan jenis unggas dapat dilihat pada tabel 4.1. Tabel 4.1 menunjukkan bahwa nilai minimum dan maksimum pada setiap variabel terpaut cukup jauh. Rata-rata persentase produksi telur dengan jenis unggas paling tinggi adalah ratarata produksi telur jenis ayam ras, yaitu sebanyak 2.080.456 produksi telur. 
Tabel 4.1 Data Produksi Telur berdasarkan Jenis Unggas

\begin{tabular}{|l|r|r|r|r|r|r|r|}
\hline \multirow{2}{*}{ Variabel } & \multicolumn{7}{|c|}{ Produksi Telur } \\
\cline { 2 - 9 } & \multicolumn{1}{|c|}{ Jumlah } & \multicolumn{1}{c|}{$\%$} & \multicolumn{1}{c|}{ Mean } & \multicolumn{1}{c|}{ Median } & Varian & Minimum & Maximum \\
\hline Ayam Kampung & 1043513 & 2.56 & $613,831,176$ & $455,630,000$ & 1.58 & 8733,00 & 172049,00 \\
\hline Ayam Ras & 35367755 & 86.82 & $20,804,561,765$ & $4,249,330,000$ & 9.586 & 1137,00 & 11882613,00 \\
\hline Itik & 3543493 & 8.70 & $2,084,407,647$ & $1,614,670,000$ & 5.054 & 12558,00 & 922846,00 \\
\hline Mentok & 91424 & 0.22 & $53,778,824$ & $46,220,000$ & 2.391 & 752,00 & 17244,00 \\
\hline Puyuh & 689860 & 1.69 & $405,800,000$ & $166,250,000$ & 4.354 & 1995,00 & 272669,00 \\
\hline
\end{tabular}

Hasill pengujian kecukupan data menunjukkan bahwa nilai KMO sebesar 0,573. Hal ini menunjukkan bahwa sampel sudah cukup dan sudah bisa mewakili populasi.

Uji Multikolinieritas menunjukkan nilai VIF untuk variabel ayam kampong sebesar 5,428, ayam ras sebesar 10,061, Itik sebesar 3,218, Mentok sebesar 2,648 dan Puyuh sebesar 4,835. Nilai VIF variabel ayam kampung, itik, mentok dan puyuh $<10$, sehingga dapat dikatakan tidak ada kasus Multikolinieritas pada variabel-variabel tersebut. Variabel Ayam Ras mempunyai nilai VIF $=10,061$. Ayam ras tetap dimasukkan dalam analisis klaster meskipun mempunyai VIF > 10 .

Hasil dari analisis K-Means klaster, setelah ditentukan jumlah kelompok ada 3 dapat dilihat pada Tabel 4.2. Sedangkan hasil akhir klaster dapat dilihat pada Tabel 4.3 .

Tabel 4.3 Hasil Akhir Klaster

\begin{tabular}{|l|r|r|r|r|r|r|r|}
\hline \multirow{2}{*}{ Variable } & \multirow{2}{*}{ Rata-Rata } & \multicolumn{3}{|c|}{ Klaster } & \multicolumn{3}{c|}{ Klaster } \\
\cline { 3 - 9 } & & 1 & 2 & 3 & 1 & 2 & 3 \\
\hline $\begin{array}{l}\text { Ayam } \\
\text { Kampung }\end{array}$ & $61.383,118$ & $85.641,6$ & 172.049 & 40.296 & Sedang & Timggi & Rendah \\
\hline Ayam Ras & $2.080 .456,2$ & $3.886 .430,2$ & 11.882 .613 & $368.453,73$ & Sedang & Timggi & Rendah \\
\hline Itik & $208.440,76$ & $110.768,4$ & 222.302 & $251.577,18$ & Sedang & Timggi & Rendah \\
\hline Mentok & $5.377,8824$ & $5.131,8$ & 5.426 & $5.485,36$ & Sedang & Timggi & Rendah \\
\hline Puyuh & 40.580 & $47.304,4$ & 272.669 & $16.424,45$ & Sedang & Timggi & Rendah \\
\hline
\end{tabular}


Tabel 4.2 Jumlah Anggota pada setiap Klaster

\begin{tabular}{|l|l|l|}
\hline \multicolumn{1}{|c|}{ Klaster I } & \multicolumn{1}{c|}{ Klaster II } & \multicolumn{1}{c|}{ Klaster III } \\
\hline Kalidawir & Rejotangan & Besuki \\
\hline Ngunut & & Bandung \\
\hline Sumbergempol & & Pakel \\
\hline Kedungwaru & & Campurdarat \\
\hline Ngantru & & Pucanglaban \\
\hline & & Boyolangu \\
\hline & & Tulungagung \\
\hline & & Karangrejo \\
\hline & & Kauman \\
\hline & & Gondang \\
\hline & & Sendang \\
\hline
\end{tabular}

Hasil analisis klaster berdasarkan tabel 4.2 adalah kelompok kecamatan yang rendah produksi telurnya (ada 11 kecamatan : Basuki, Bandung, Pakel, Campurdarat, Pucanglaban, Boyolangu, Tulungagung, Karangrejo, Kauman, Gondang, dan Sendang), kelompok kecamatan dengan produksi telur sedang (ada 5 kecamatan : Kalidawir, Ngunut, Sumbergempol, Kedungwaru dan Ngantru), sedangkan kelompok kecamatan dengan produksi telur tinggi adalah kecamatan Rejotangan.

Rata-rata produksi telur menurut jenis unggas per klaster dapat dilihat pada tabel 4.3. Tabel 4.3 menunjukkan bahwa pada kelompok kecamatan produksi telur rendah rata-rata produksinya pada tahun 2011 adalah sebesar $40.296 \mathrm{~kg}$ untuk ayam kampung, 368.453,73 kg untuk ayam ras, 251.577,18 kg untuk itik, $5.485,36 \mathrm{~kg}$ untuk mentok dan $16.424,45 \mathrm{~kg}$ untuk puyuh. Sedangkan pada kelompok kecamatan produksi telur tinggi rata-rata produksinya pada tahun 2011 adalah sebesar $172.049 \mathrm{~kg}$ untuk ayam kampung, $11.883 .613 \mathrm{~kg}$ untuk ayam ras, $222.302 \mathrm{~kg}$ untuk itik, $5.426 \mathrm{~kg}$ untuk mentok dan $272.669 \mathrm{~kg}$ untuk puyuh. 


\section{Simpulan}

Hasil analisis klaster $K$-Means diperoleh 3 kelompok, yaitu kelompok kecamatan yang rendah produksi telurnya (ada 11 kecamatan : Basuki, Bandung, Pakel, Campurdarat, Pucanglaban, Boyolangu, Tulungagung, Karangrejo, Kauman, Gondang, dan Sendang), kelompok kecamatan dengan produksi telur sedang (ada 5 kecamatan : Kalidawir, Ngunut, Sumbergempol, Kedungwar Ngantru), sedangkan kelompok kecamatan dengan produksi telur tinggi adalah kecamatan Rejotangan.

\section{DAFTAR PUSTAKA}

Badan Pusat Statistik Tulungagung. (2012). Tulungagung Dalam Angka 2012. BPS : Tulungagung.

Johnson, N. and Wichern, D. (1998). Applied Multivariate Statistical Analysis, Prentice-Hall, Englewood Cliffs, N.J.

Sharma, S. 1996. Applied Multivariate Techniques, John Wiley \& Company LOGO Sons, Inc 
44) Pengelompokkan Kecamatan Di Tulungagung Berdasarkan Produksi Telur Menurut Jenis Unggas Dengan Menggunakan Analisis Klaster 